\title{
PENGARUH PEMBERIAN JENIS AMELIORAN TERHADAP PERTUMBUHAN DAN PRODUKSI BAYAM (Amaranthus tricolor L.) PADA TANAH GAMBUT
}

\author{
The Efect of Ameliorant on the Growth and the Harvest of Spinach \\ (Amaranthus tricolor L.) on the Peat Land
}

\author{
Yunita Purnama Sari ${ }^{1}$, Haryadi ${ }^{2}$ dan Fahruddin Arfianto ${ }^{3}$ \\ ${ }^{\mathbf{1 , 2 , 3}}$ Program Studi Agroteknologi, Fakultas Pertanian dan Kehutanan \\ Universitas Muhammadiyah Palangkaraya \\ Email: ${ }^{1}$ yunitaps07@gmail.com, ${ }^{2}$ haryadi_ump@yahoo.co.id, \\ fahruddin237@gmail.com
}

\begin{abstract}
The lowness of productivity of spinach in Central Kalimantan is related to the kind of land used in the cultivation of the crop. This research attempt to find the effect of ameliorant on the growth and the harvest of spinach. The research was conducted from December 2018 until February 2019 in Kebun Percobaan dan Penelitian (KP2) Universitas Muhammadiyah Palangkaraya, Jln. Anggrek, Kelurahan Kereng Bengkirai, Kecamatan Sebangau, Kota Palangkaraya, Provinsi Kalimantan Tengah. The ameliorant applied in the research were chicken manure, dolomite and limestone. The research was conducted in the completely random design with five replications. The results indicate that the ameliorant significantly affected the plant height and the number of leaves on the 14, 21 and 28 day after plantation. The ameliorant also affected on the plant fresh weight significantly.
\end{abstract}

Keywords: spinach, ameliorants, peat land.

\begin{abstract}
ABSTRAK
Rendahnya produktivitas bayam di Kalimantan Tengah tidak terlepas dari jenis lahan untuk budidaya tanaman tersebut, yaitu sebagian berupa tanah gambut. Penelitian ini bertujuan untuk mengetahui pengaruh pemberian jenis amelioran terhadap pertumbuhan dan produksi bayam pada tanah gambut. Penelitian dilaksanakan pada bulan Desember 2018 s/d Februari 2019, diKebun Percobaan dan Penelitian (KP2) Universitas Muhammadiyah Palangkaraya, Jln. Anggrek, Kelurahan Kereng Bengkirai, Kecamatan Sebangau, Kota Palangkaraya, Provinsi Kalimantan Tengah. Faktor amelioran yang digunakan terdiri atas 3 perlakuan, yaitu pupuk kandang ayam, kapur dolomit dan kapur gamping. Penelitian dilaksanakan dengan Rancangan Acak Lengkap (RAL) dengan 5 ulangan.Hasil penelitian menunjukkan bahwa jenis amelioran berpengaruh sangat nyata terhadap tinggi tanaman bayam dan jumlah pada umur 14, 21 dan 28 HST. Jenis amelioran juga berpengaruh nyata terhadap berat segar tanaman.
\end{abstract}

Kata kunci :amelioran, tanaman bayam dan tanah gambut 


\section{PENDAHULUAN}

\section{Latar belakang}

Bayam yang semula dikenal sebagai tanaman hias, dalam perkembangannya dipromosikan sebagai bahan pangan yang mengandung sumber protein nabati, terutama di negara-negara berkembang. Selain itu bayam mengandung vitamin $\mathrm{A}, \mathrm{B}$ dan $\mathrm{C}$ serta mengandung kalsium, fosfor dan besi (Sunarjo, 2003). Manfaat lainnya dari bayam adalah sabagai bahan obat tradisional, bahan kosmetik (kecantikan) dan bahan campuran pembuatan tepung.

Produktivitas rata-rata bayam di Kalimantan Tengah pada tahun 2013 sebesar 2.29 ton/ha dan mengalami penurunan pada tahun 2014 sebesar 1.64 ton/ha. Produktivitas tersebut lebih rendah dibandingkan dengan produktivitas bayam secara nasional, yaitu pada tahun 2013 sebesar 3.11 ton/ha dan pada tahun 2014 sebesar 2.96 ton/ha produktivitas (Badan Pusat Statistik, 2014).

Dari sisi luas lahan, budidaya tanaman bayam di Kalimantan Tengah masih relatif rendah yang disebabkan karena lahan pertanian yang didominasi oleh tanah gambut. Pengembangan pertanian di lahan gambut dihadapkan pada berbagai kendala yang berkaitan dengan sifat tanah gambut.
Lahan gambut tanah kaya akan bahan organik yang terbentuk dari sisa sisa tanaman yang belum melapuk sempurna karena kondisi jenuh air dan miskin hara. Oleh karena itu gambut banyak dijumpai pada daerah cekungan yang draenasenya buruk atau rawa belakang.

Indonesia memiliki area terluas di zona tropis, diperkirakan mencapai 21 juta ha jika dipresentasekan $70 \%$ areal gambut di Asia Tenggara dan 50\% dari lahan gambut di dunia (Wibowo, 2009). Lahan gambut di Indonesia berpusat di tiga pulau besar yaitu Sumatera 35\%, Kalimantan $32 \%$, Papua $30 \%$ dan pulau lainnya $3 \%$ dengan total 21 juta ha (Wahyunto dan Heryanto, 2005). Menurut Wahyunto dan Subiksan (2011), lahan gambut di Indonesia tersebar mulai dari daerah dataran rendah dan daerah dataran tinggi.

Lahan gambut merupakan lahan marginal untuk pertanian karena kesuburannya yang rendah, bersifat sangat masam, kapasitas tukar kation yang tinggi, kejenuhan basa yang rendah, kandungan unsur $\mathrm{K}, \mathrm{Ca}, \mathrm{Mg}, \mathrm{P}$ dan mikro seperti $\mathrm{Cu}$, $\mathrm{Zn}, \mathrm{B}, \mathrm{Mn}$ juga rendah. Keterbatasan lahan bertanah mineral, menyebabkan ekstensifikasi pertanian ke lahan gambut tidak dapat dihindari (Subagyo dan Karama, 1996). Dengan penambahan 
bahan-bahan yang banyak mengandung kation polivanel seperti $\mathrm{Al}, \mathrm{Fe}, \mathrm{Cu}$ dan $\mathrm{Zn}$ dapat mengurangi asam - asam organik yang berpengaruh buruk pada tanaman (Rachim, 1999). Menurut Subagyo dan Karama (1996) jenis amelioran seperti kapur, abu janjang kelapa sawit, abu sekam padi dan pupuk kandang dapat meningkatkan unsur hara dan tekstur atau sifat fisik tanah gambut.

Dengan memperhatikan potensi amelioran untuk memperbaiki sifat kimia, fisik dan biologi tanah gambut maka penulis merasa termotivasi untuk mengaplikasikan amelioran dengan tujuan untuk meningkatkan hasil produktivitas tanaman bayam.

\section{Tujuan Penelitian}

Penelitian ini bertujuan untuk mengetahui pengaruh pemberian jenis amelioran terhadap pertumbuhan dan produksi bayam pada tanah gambut. Jenis amelioran dalam penelitian ini meliputi pupuk kandang ayam, kapur dolomite dan kapur gamping.

\section{Kajian Pustaka}

Bayam dapat tumbuh disepanjang tahun, baik di dataran rendah maupun dataran tinggi. Oleh karena itu tanaman ini dapat ditanam di kebun dan perkarangan rumah. Waktu penanaman yang baik ialah pada awal musim hujan atau pada awal musim kemarau. Bayam akan tumbuh dengan baik jika ditanam di tanah dengan pH antara 6 - 7. Apabila pH kurang dari 6, pertumbuhan tanaman akan terganggu. Sedangkan pada $\mathrm{pH}$ di atas 7 , tanaman bayam akan mengalami klorosis, yaitu timbulnya warna putih kekuningkuningan, terutama pada daun yang masih muda (Sunarjo, 2003).

Faktor lain yang mempengaruhi pertumbuhan dan produksi tanaman bayam antara lain ketinggian tempat, sinar matahari, suhu dan kelembaban. Bayam banyak ditanam pada ketinggian antara 5 $2000 \mathrm{~m}$ dpl. Kebutuhan sinar matahari untuk tanaman bayam berkisar antara 400 - 800 foot candles yang akan mempengaruhi pertumbuhan optimum dengan suhu rata - rata $20-30^{\circ} \mathrm{C}$, curah hujan antara $1000-2000 \mathrm{~mm}$ dan kelembaban di atas 60\% (Bandini dan Aziz, 2001).

Tanah gambut adalah tanah yang mengandung minimal $30 \%$ bahan organik dengan ketebalan kumulatif $40 \mathrm{~cm}$ atau lebih. Penyebaran tanah gambut di Indonesia cukup luas, terutama di jumpai di sepanjang pantai Timur Sumatera, pantai Selatan dan Barat Kalimantan dan pantai Selatan Irian Jaya, sebagian besar 
masih kawasan hutan dan hanya sebagian kecil yang sudah diusahakan menjadi lahan pertanian dan perkebunan.

Balai Besar Penelitian dan Pengembangan Sumberdaya Lahan Pertanian (2011) mengungkapkan bahwa luas tanah gambut di Kalimantan Tengah sekitar 2.659.234 hektar. Luasan tersebut menjelaskan bahwa pemanfaatan tanah gambut menjadi salah satu sorotan dalam pengembangan budidaya pertanian. Pengelolaan tanah gambut umumnya dengan perbaikan tata air, melalui pembuatan saluran drainase sehingga dapat ditanami. Pemberian amelioran berupa kapur dan pupuk kandang diperlukan untuk membantu memperbaiki sifat fisik dan kimia tanah gambut.

Amelioran adalah bahan yang dapat meningkatkan kesuburan tanah melalui perbaikan kondisi fisik dan kimia. Amelioran dapat berupa bahan organik dan anorganik. Kriteria amelioran yang bagi lahan gambut adalah yang memiliki kejenuhan basa (KB) yang tinggi, mampu meningkatkan derajat $\mathrm{pH}$ secara nyata, mampu memperbaiki struktur tanah, memiliki kandungan unsur hara yang lengkap dan mampu mengusir senyawa beracun terutama asam - asam organik (Susilawati, 2011).
Pemberian bahan amelioran seperti pupuk organik, tanah mineral, zeolit, dolomit, fosfat alam, pupuk kandang, kapur pertanian, abu sekam, purun tikus (Eleocharis dulcis) dapat meningkatkan pH tanah dan basa - basa tanah (Salampak, 1999). Penambahan bahan - bahan amelioran yang banyak mengandung kation polivalen juga dapat mengurangi pengaruh buruk asam - asam organik yang bersifat racun, penambahan kation $\mathrm{Fe}^{+}$juga dapat menekan emisi etana pada lahan gambut.

Harjdowigeno (2003) menjelaskan apabila dibandingkan antara berbagai macam pupuk kandang lainnya, pupuk kandang ayam mempunyai nilai hara yang tertinggi karena bagian cair tercampur dengan bagian padat, pupuk kandang ayam mengandung $\mathrm{N}$ tiga kali lebih banyak dari pada pupuk kandang lainnya. Beberapa hasil penelitian aplikasi pupuk kandang ayam selalu memberikan respon tanaman yang terbaikpada musim pertama. Hal ini karena pupuk kandang ayam relatif lebih cepat terkomposisi serta mempunyai kadar hara yang cukup dibandingkan dengan jumlah unit yang sama dengan pupuk kandang hewan lainnya.

Unsur - unsur hara yang terkandung dalam pupuk kandang ayam adalah nitrogen $(\mathrm{N}) 12,5 \mathrm{~kg} / \mathrm{ton}$, fospor $(\mathrm{P})$ 
$5,5 \mathrm{~kg} / \mathrm{ton}$, kalium (K) $5 \mathrm{~kg} /$ ton,kalsium (Ca) $18 \mathrm{~kg} / \mathrm{ton}$, magnesium $(\mathrm{Mg}) 3 \mathrm{~kg} / \mathrm{ton}$, sulfur (S) 1,6 kg/ton, ferrum (Fe) 1,15 $\mathrm{kg} / \mathrm{ton}$, boron (B) $0,005 \mathrm{~kg} / \mathrm{ton}$, cuprun (Cu) 0,005 kg/ton, zinc (Zn) 0,005 kg/ton (Rosmarkam dan dan Yuwono, 2002).

Dolomit merupakan pupuk yang berasal dari endapan mineral sekunder yang banyak mengandung unsur $\mathrm{Ca}$ dan $\mathrm{Mg}$ dengan rumus kimia $\mathrm{CaMg}\left(\mathrm{CO}_{3}\right)_{2}$ (Kartono, 2010). Dolomit yang digunakan sebagai bahan pengapuran selain meningkatkan $\mathrm{pH}$ tanah juga mengurangi keracunan $\mathrm{Fe}, \mathrm{Al}$ dan $\mathrm{Mn}$ serta meningkatkan ketersediaan unsur hara yang lebih baik (Sutejo, 1995).

Dolomit diproduksi menggunakan bahan baku kapur yang memiliki kadar atau presentase kalsium $(\mathrm{CaO})$ dan magnesium ( $\mathrm{MgO})$ yang tinggi. Keuntungan menggunakan dolomit dapat menetralkan $\quad \mathrm{pH}, \quad$ meningkatkan pertumbuhan akar, dan memperbaiki struktur tanah, meningkatkan mutu seperti hasil yang tinggi dan buah yang berat, serta dapat digunakan sebagai pupuk dasar dan pupuk susulan (Kartono, 2010).

Menurut Lingga (1990) jika tanah gambut dengan $\mathrm{pH} \quad 5,5$ maka dosis anjurannya adalah 3,12 ton/ha. Selain dapat menetralkan $\mathrm{pH}$ dolomit juga dapat membantu mematikan jamur dan bakteri sehingga akan meningkatkan kesuburan tanah (Kartono, 2010).

Kapur gamping merupakan batuan fosfat, batuan ini sendiri terbentuk dari kalsium karbonat atau $\mathrm{CaCO}_{3}$. Kalsium karbonat adalah senyawa penting yang terdiri dari satu atom kalsium terikat pada satu atom karbon dan tiga atom oksigen.

Senyawa ini biasanya terlihat seperti bubuk putih atau batu, dan akan melepaskan karbon dioksida saat terjadi kontak dengan asam kuat, seperti asam klorida. Setelah karbon dioksida dilepaskan, sisanya adalah kalsium oksida atau kapur.

Kapur gamping mengacu pada batuan yang mengandung setidaknya $50 \%$ berat kalsium karbonat dalam bentuk mineral kalsit. Sisanya kapur gamping mengandung beberapa mineral seperti kuarsa, feldspar, mineral lempung, pirit, siderite dan mineral - mineral lainnya. Bahkan kapur gamping juga mengandung nodul besar rijang dan nodul pirit ataupun nodul siderit.

\section{METODOLOGI}

\section{Waktu dan Tempat}

Penelitian ini dilaksanakan pada bulan Desember 2018 sampai dengan bulan Februari 2019, dilaksanakan di green house, kebun percobaan dan penelitian 
(KP2) Universitas Muhammadiyah Palangkaraya, Jln. Anggrek, Kelurahan Kereng Bengkirai, Kecamatan Sebangau, Kota Palangkaraya, Provinsi Kalimantan Tengah.

\section{Bahan dan Alat}

Bahan - bahan yang digunakan dalam penelitian ini adalah benih bayam, pupuk kandang ayam, kapur dolomit, dan kapur gamping. Alat- alat yang digunakan adalah polybag ukuran 35 x $40 \mathrm{~cm}$, ayakan tanah ukuran 16 mesh, cangkul, parang, ember, gelas air mineral, timbangan analitik, kamera, penggaris, alat tulis dan alat lainnya yang menunjang kelancaran penelitian.

\section{Rancangan Penelitian}

Penelitian ini menggunakan Rancangan Acak Lengkap (RAL) satu faktor yang terdiri dari 3 pelakuan dan 5 ulangan dengan dosis 10 ton/ha, sehingga untuk keseluruhan percobaan berjumlah 15 satuan percobaan. Ketiga perlakuan tersebut adalah:

$\mathrm{K}$ : pupuk kadang ayam dengan dosis 10 ton/ha

D : kapur dolomit dengan dosis 10 ton/ha

G : kapur gamping dengan dosis 10 ton/ha

\section{Persiapan Media Tanam}

Media tanam yang digunakan berupa tanah gambut dengan kematangan saprik. Tanah gambut diambil pada kedalaman $20 \mathrm{~cm}$ dari permukaan tanah, kemudian dikering anginkan selama 1 minggu. Tanah dibersihkan dari sisa - sisa akar tumbuhan dan diayak menggunakan kawat berukuran 16 mesh tiap lubangnya. Setelah diayak tanah gambut dimasukan kedalam polybag ukuran 35 x $40 \mathrm{~cm}$ dengan berat $3 \mathrm{~kg} /$ polybag, kemudian dicampur sampai rata dengan pupuk kadang ayam, kapur dolomit, dan kapur gamping sesuai dengan perlakuan percobaan, kemudian diinkubasi selama 2 minggu.

\section{Penanaman}

Pada penanaman, benih langsung ditanam di dalam polybag percobaan yang sudah diberikan perlakuan. Penanaman dengan cara menabur benih di atas permukaan tanah yang sudah disediakan di dalam polybag. Penanaman dilakukan pada sore hari.

\section{Pemeliharaan}

Pemeliharaan tanaman meliputi: penyiangan, penyiraman, pembumbunan, pemupukan, pengendalian hama dan penyakit.

\section{a. Penyiangan}


Penyiangan dilakukan dengan mencabut rumput - rumput atau gulma lainnya yang tumbuh di sekitaran tanaman.

b. Penyiraman

Penyiraman dilakukan secara rutin 1 kali sehari yaitu sore hati. Saat umur tanaman $0-10$ HST volume penyiraman diberikan secukupnya hingga tanah basah merata. Kemudian saat umur tanaman 11 - 20 HST volume penyiraman dinaikkan menjadi 500 $\mathrm{ml} /$ polybag.

c. Pembumbunan

Pembumbunan dilakukan bila tanah terlihat padat atau akar mulai timbul di permukaan dengan cara mempertinggi permukaan tanah di sekitar tanaman agar aerase tanah lebih baik.

d. Pemupukan

Selain perlakuan amelioran, tanaman juga diberi pemupukan rutin yang dilakukan pada usia 14 dan 21HST. Pupuk yang digunakan yaitu pupuk urea dengan dosis 0,3 g/polybag dan cara aplikasinya dengan dibenamkan kedalam tanah pada sekitar tanaman bayam.

\section{Pengamatan}

Variabel yang diamati adalah:

a. Tinggi Tanaman $(\mathrm{cm})$
Tinggi tanaman diukur dari pangkal batas tanaman sampai dengan ujung titik tumbuh tertinggi. Pengamatan dilakukan saat tanaman berumur 14, 21 dan 28 HST.

b. Jumlah Daun (helai) Jumlah daun yang dihitung yaitu daun yang telah membuka penuh dan minimal 50\%, masih berwarna hijau. Perhitungan jumlah daun dilakukan pada umur 14, 21 dan 28 HST.

c. Berat Segar Tanaman (gram)

Berat segar tanaman diperoleh dengan cara menimbang seluruh tajuk tanaman setelah dibersihkan dan dipisahkan dari akar, dalam keadaan segar saat panen.

\section{Analisis Data}

Data dianalisis dengan menggunakan analisis ragam (Uji F) pada taraf 5\%. Apabila Uji F menunjukan adanyapengaruh perlakuan, maka dilanjutkan dengan Uji BNT 5\%.

\section{HASIL DAN PEMBAHASAN}

\section{Hasil}

Rekapitulasi hasil pengamatan analisis ragam pertumbuhan dan produksi bayam pada umur 14, 21 dan 28 HTS disajikan pada Tabel 1. 
Tabel 1. Rekapitulasi hasil analisis ragam tanaman bayam umur 14, 21 dan 28HST.

\begin{tabular}{cccccccc}
\hline Variabel & \multicolumn{3}{c}{ Tinggi tanaman } & \multicolumn{3}{c}{ Jumlah daun } & Berat segar tanaman \\
\hline Umur (HST) & 14 & 21 & 28 & 14 & 21 & 28 & 28 \\
\hline Perlakuan & $* *$ & $* *$ & $* *$ & $* *$ & $* *$ & $* *$ & $* *$ \\
\hline
\end{tabular}

Keterangan :

** : Berbeda sangat nyata

\section{Tinggi Tanaman}

Hasil analisis ragam menunjukkan bahwa perlakuan pemberian amilioran pupuk kandang ayam, kapur dolomit dan kapur gamping memberikan pengaruh yang sangat berbeda nyata pada tinggi tanaman 14, 21 dan 28 HST. Hasil uji beda rata - rata tinggi tanaman bayam pada umur 14, 21 dan 28 HST disajikan pada Tabel 1.

Tabel 1.Rata - rata tinggi tanaman bayam (cm) pada umur 14, 21 dan 28 HST.

\begin{tabular}{cccc}
\hline Perlakuan & \multicolumn{3}{c}{ Rata - rata tinggi tanaman $(\mathrm{cm})$} \\
\cline { 2 - 4 } & $14 \mathrm{HST}$ & $21 \mathrm{HST}$ & $28 \mathrm{HST}$ \\
\hline $\mathrm{K}$ & $11,78^{\mathrm{a}}$ & $30,24^{\mathrm{a}}$ & $42,4^{\mathrm{a}}$ \\
\hline $\mathrm{D}$ & $9,28^{\mathrm{b}}$ & $24,02^{\mathrm{b}}$ & $32,92^{\mathrm{b}}$ \\
\hline G & $7,06^{\mathrm{c}}$ & $14,42^{\mathrm{c}}$ & $19,62^{\mathrm{b}}$ \\
\hline BNT 5\% & 1,68 & 5,07 & 5,83
\end{tabular}

Keterangan : Angka - angka yang diikuti notasi yang sama pada kolom yang sama, tidak berbeda nyata menurut uji BNT 5\%.

Berdasarkan Tabel 1, menunjukkan bahwa tinggi tanaman pada umur 14 dan 21 HST semua perlakuan berbeda nyata, sedangkan pada umur 28 HST K berbeda nyata dengan perlakuan D dan G. Akan tetapi perlakuan D tidak berbeda nyata dengan perlakuan $\mathrm{G}$.

\section{Jumlah Daun}

Hasil analisis ragam menunjukkan bahwa perlakuan pemberian amilioran pupuk kandang ayam, kapur dolomit dan kapur gamping memberikan pengaruh yang sangat berbeda nyata pada jumlah daun tanaman bayam pada umur 14, 21 dan 28 HST. Hasil uji beda rata - rata jumlah daun tanaman bayam pada umur 14, 21 dan 28 HST disajikan pada Tabel 2. 
Tabel 2. Hasil rata - rata jumlah daun tanaman bayam pada umur 14, 21 dan 28 HST.

\begin{tabular}{cccc}
\hline Perlakuan & \multicolumn{3}{c}{ Rata - rata jumlah daun (helai) } \\
\cline { 2 - 4 } & 14 HST & 21 HST & 28 HST \\
\hline K & $5,4^{\mathrm{a}}$ & $14,2^{\mathrm{a}}$ & $17,6^{\mathrm{a}}$ \\
\hline $\mathrm{D}$ & $4,2^{\mathrm{b}}$ & $10,6^{\mathrm{b}}$ & $15,2^{\mathrm{ab}}$ \\
\hline G & $4^{\mathrm{b}}$ & $10,2^{\mathrm{b}}$ & $13^{\mathrm{b}}$ \\
\hline BNT 5\% & 0,57 & 2,39 & 3,02
\end{tabular}

Keterangan: Angka - angka yang diikuti notasi yang sama pada kolom yang sama, tidak berbeda nyata menurut uji BNT 5\%.

Dari Tabel 2 menunjukkan bahwa hasil tertinggi untuk variabel pengamatan jumlah daun umur 14 HST menggunakan perlakuan $\mathrm{K}$ dengan rata - rata 5,4 helai berbeda nyata dengan $\mathrm{D}$ namun tidak berbeda nyata dengan G. Sedangkan pada umur 21 dan 28 HST perlakuan D dan G berbeda nyata dengan perlakuan $\mathrm{K}$.
Hasil analisis ragam menunjukkan bahwa perlakuan pemberian ameliorant pupuk kandang ayam, kapur dolomit dan kapur gamping memberikan pengaruh yang sangat berbeda nyata pada berat segar tajuk pada umur $28 \mathrm{HST}$.

Hasil uji beda rata - rata berat segar tajuk pada umur 28 HST disajikan pada Tabel 3.

\section{Berat Segar Tajuk}

Tabel 3. Hasil uji rata - rata berat segar tanaman bayam umur 28HST.

\begin{tabular}{cc}
\hline Perlakuan & Berat Segar Tanaman (gram) \\
\hline K & $2,08^{\mathrm{a}}$ \\
\hline $\mathrm{D}$ & $1,08^{\mathrm{b}}$ \\
\hline $\mathrm{G}$ & $0,28^{\mathrm{c}}$ \\
\hline BNT 5\% & 0,41
\end{tabular}

Keterangan : Angka - angka yang diikuti notasi yang sama pada kolom yang sama, tidak berbeda nyata menurut uji BNT 5\%.

Berdasarkan Tabel 3, menunjukan bahwa hasil tertinggi variabel pengamatan berat segar tanaman diperoleh perlakuan $\mathrm{K}$ dengan rata - rata 2,08 gram berbeda nyata dengan perlakuan D dan perlakuan G. 


\section{Pembahasan}

Berdasarkan hasil pengamatan terhadap variabel pengamatan pertumbuhan dan produksi tanaman bayam yang meliputi tinggi tanaman, jumlah daun dan berat segar tajuk dengan perlakuan pemberian beberapa jenis ameliorant yang meliputi pupuk kandang ayam, kapur dolomit dan kapur gamping, secara umum berpengaruh sangat nyata terhadap tinggi tanaman bayam, jumlah daun dan berat segar tajuk pada umur 14, 21 dan 28 HST.

Hasil analisis ragam variabel tinggi tanaman menunjukkan bahwa pada umur 14 HST dan 21 HST ketiga jenis amilioran berbeda nyata, sedangkan pada umur 28 HST perlakuan $\mathrm{K}$ berbeda nyata dengan perlakuan D namun tidak berbeda nyata dengan G. Demikian pula, perlakuan D tidak berbeda nyata dengan perlakuan $\mathrm{G}$.

Pengamatan jumlah daun menunjukkan bahwa hasil tertinggi untuk variabel pengamatan jumlah daun umur 14 HST menggunakan perlakuan $\mathrm{K}$ dengan rata - rata 5,4 helai berbeda nyata dengan D namun tidak berbeda nyata dengan $G$. Sedangkan pada umur 21 dan 28 HST perlakuan $\mathrm{D}$ dan $\mathrm{G}$ berbeda nyata dengan perlakuan K.

\footnotetext{
Pada variabel pengamatan berat segar tajuk menunjukkan bahwa hasil tertinggi variabel pengamatan berat segar
}

tanaman diperoleh perlakuan $\mathrm{K}$ dengan rata - rata 2,08 gram berbeda nyata dengan perlakuan D dan perlakuan G.

Adanya pengaruh yang lebih baik pada pemberian amilioran pupuk kandang ayam dibandingkan dengan amilioran kapur dolomit maupun gamping, disebabkan oleh adanya perbedaan kandungan hara yang menunjang pertumbuhan vegetatif tanaman bayam.Pupuk kandang ayam lebih banyak mengandung unsur hara nitrogen yang mampu memacu pertumbuhan vegetatifnya (Dwidjoseputra, 2000).

Pupuk kandang ayam juga mengandung $\mathrm{N}$ tiga kali lebih banyak dari bahan organik lainnya. Tingginya kadar $\mathrm{N}$ pada pupuk kandang ayam disebabkan karena pupuk tersebut relatif lebih mudah terdekomposisi (Hartatik dan Widowati, 2007). Dengan ketersediaan N yang cukup, mengakibatkan pertumbuhan pada fase vegetatif menjadi optimal seperti merangsang pertumbuhan cabang batang dan daun.Sedangkan unsur hara yang terkandung dalam pupuk kandang ayam adalah $\mathrm{N}, \mathrm{P}, \mathrm{K}, \mathrm{Ca}, \mathrm{Mg}, \mathrm{S}, \mathrm{Fe}, \mathrm{B}, \mathrm{Cu}$ dan Zn (Rosmarkam dan Yuwono, 2002). 


\section{KESIMPULAN DAN SARAN}

\section{Kesimpulan}

Hasil penelitian menunjukkan bahwa amilioran pupuk kadang ayam, kapur dolomit dan kapur gamping yang diberikan pada tanaman bayam memberikan pengaruh pada variabel pengamatan sebagai berikut:

a. Pemberian amelioran pupuk kandang ayam memberikan pengaruh paling baik terhadap pertumbuhan tanaman dibandingkan dengan dua perlakuan amilioran lainnya, yang ditunjukkan dengan tinggi tanaman dan jumlah daun pertanaman paling tinggi dibandingkan dengan dua perlakuan lainnya.

b. Pemberian amelioran pupuk kandang ayam memberikan pengaruh paling baik terhadap berat segar tanaman dibanding amelioran kapur dolomit maupun kapur gamping

\section{Saran}

Untuk budidaya tanaman bayam di tanah gambut disarankan menggunakan jenis amelioran yang kandungan unsur haranya lebih lengkap seperti amelioran pupuk kandang ayam yang banyak mengandung nitrogen lebih banyak untuk membantu pertumbuhan pada fase vegetatif.

\section{DAFTAR PUSTAKA}

Badan Pusat Statistik. 2014. Kalimantan Tengah Dalam Angka 2014. Palangkaraya.

Balai Besar Penelitian dan Pengembangan Sumber Daya Lahan Pertanian BBSDLP. 2011. Teknologi Pengelolaan Lahan Gambut Berkelanjutan Untuk Meningkatkan Sekuestasi Karbon Dan Mitigasi Gas Rumah Kaca. Balai Besar Litbang Sumber Daya Lahan Pertanian. Bogor.

Bandini, Y dan Ajis, N. 2001.Bayam. Penebar Swadaya. Jakarta.

Harjdowigono, S. 2003. Ilmu tanah.

Akademika Presindo. Jakarta.

Hartatik dan Widowati, 2007. Pupuk organic dan pupuk hayati organic fertilizer and biofertilizer. Balai Besar Litbang Sumberdaya Lahan Pertanian Bogor.

Kartono, R. 2010. Katalog Produk Pupuk Dolomit A100 Lulus 96\%. Penebar Swadaya. Jakarta.

Lingga. 1990. Petunjuk Penggunaan Pupuk. Penebar Swadaya. Jakarta.

Rachim, A. 1999. Penggunaan kationkation polivalen dalam kaitannya dengan keterbatasan fosfat untuk meningkatkan produksi jagung pada 
tanah gambut. Disertasi. Program pascasarjana. IPB. Bogor.

Rosmarkam dan Yuwono. 2002. Ilmu Kesuburan Tanah. Kanisis. Jakarta.

Salampak. 1999. Peningkatan

Produktivitas Tanah Gambut Yang

Disawahkan Dengan Pemberian

Bahan Amelioran Tanah Mineral

Berkadar Besi Tinggi. Disertasi.

Program Pascasarjana.IPB. Bogor.

Subagyo, M. dan Karama, S. 1996.

Prospek Pengembangan Lahan

Gambut. Penebar Swadaya. Jakarta.

Sunarjo, H. 2003. Bertanam 30 Jenis

Sayuran. Penebar Swadaya. Jakarta.

Susilawati. 2011. Emiliorasi Tanah Gambut Meningkatkan Produksi

Padi Dan Menekan Emisi Gas

Rumah Kaca. Badan Penelitian Dan

Pengembangan Pertanian. Bogor.

Sutejo, M. M. 1995. Pupuk Dan

Pemupukan. Rineka Cipta. Jakarta.

Wahyunto dan Heryanto, B. 2005.Sebaran

Gambut Dan Status Terkini Di

Sumatera. Dalam CCFPI. 2005.

Pemanfaatan Gambut Secara

Bijaksana Untuk Manfaat

Berkelanjtan. Prosiding

Lokakarya.Indonesia Programe.

Bogor.
Wahyunto dan Subiksa, I. G. M. 2011. Genesis Lahan Gambut. Penebar Swadaya. Bogor.

Wibowo, H. 2009. Laju Infiltrasi Pada Lahan Gambut Yang Dipengaruhi Air Tanah. Jurnal Berian 9 (1): 90103. 